\title{
Difference Analysis of Social Performance With The Islamic Social Reporting (ISR) in Syariah Banking That Are in Indonesia and Malaysia Aprila Dwi Widayati $^{1 *}$ and Raditya Sukmana ${ }^{2}$
}

\author{
${ }^{1,2}$ Airlangga University, Surabaya, Indonesia
}

\begin{abstract}
The purpose of this research is to examine the difference of Islamic Social Reporting (ISR) disclosure level of islamic banking in Indonesia and Malaysia based on ISR index. The samples were selected by purposive sampling method. The samples that is used in this research is five islamic banks in Indonesia and five islamic banks in Malaysia. This research uses secondary data, that is annual report from 2010-2012. Annual reports were analyzed using content analysis method. Furthermore, the differences of ISR disclosure level were tested using independent sample t-test. The results showed that ISR disclosure level of islamic banking in Indonesia is better than ISR disclosure level of islamic banking in Malaysia. Based on the results of hypothesis testing, found that there are significant differences in the disclosure level between islamic banking in Indonesia and Malaysia.
\end{abstract}

Keywords: Islamic Social Reporting, Islamic Social Reporting Index, Islamic Banking

\section{INTRODUCTION}

With the massive development of global economics it is unavoidable that every company today is demanded by the people to not only think about how to increase company profits but also care for the environment and the people around it. Other than that, companies are also demanded to express social responsibility that have been implemented in the yearly report precisely for an added value to companies.

In unanimous with the development of syariah banking internationally and related with the presence of demands in expressing social responsibility in a company. Islamic Social Reporting has become the current topic. Islamic Social Reporting is an expansion of social reporting that have Islamic values already inserted inside it for aiding Islamic companies in expressing their responsibility in yearly reports.

In the 1990s period, the financial sector in Indonesia expanded more and more with the presence of financial institutions that operate based on the principles of Islamic teachings or Islamic syariah. Although Indonesia is a country with a majority muslim population, Indonesia is not the first country to apply financial institutions based on syariah principles of $45.4 \%$. Meanwhile Malaysia has previously established a syariah bank far before Indonesia or in other words Malaysia is a pioneer of syariah banking in Southeast Asia with a growth of syariah banking assets that is very high in the world.

* Corresponding author. Email address: adwidayati@gmail.com 
The ISR index is a measure of the implementation of social responsibilities of syariah banking that consists of a compilation of standard items that are assigned by AAOIFI (Accounting and Auditing Organization for Islamic Financial Institutions) that should be stated by an Islamic entity.

Hanniffa (2002) contends that the report of corporate social responsibility in the conventional system only focuses on moral and material aspects. He adds that the spiritual and material aspects should also be a main focus in corporate social responsibility reports because the Muslim decision makers have expectations so that companies reveal the newest information voluntarily for aiding in their fulfillment of spiritual needs. Because of that, he views that there is a need for the presence of a specific frame for reporting social responsibility that is in accordance with Islamic principles. The mentioned frame is not only useful for the Muslim decision makers, but also useful for Islamic companies in fulfilling their responsibility to Allah SWT and the people. This frame is known by the name of Islamic Social Reporting (ISR).

The social reporting that is in accordance with Islamic principles will be more and more visible in the social reporting of Islamic banks. Islamic Banks that operate ideally are based on the principles of Islamic law and as one of the forms of Islamic business clearly its social reporting will be based on Islamic principles (Haniffa, 2002)

Problem Formulation

Is there a difference in the disclosure of Islamic Social Reporting (ISR) in syariah banking that are in Indonesia and Malaysia reviewed from the 2012-2014 period?

Research Purpose

For analyzing disclosure differences of Islamic Social Reporting in syariah banking that are in Indonesia and Malaysia reviewed from the 2012-2014 period.

\section{LITERATURE BASE}

Disclosure simply can be meant as an expenditure of information (Sudarmadji and Sularto, 2007). Evans, 2003 (in Raditya, 2012:23) declared that disclosure has the meaning of providing information in a financial report that covers the financial report itself, notes of the financial report and additional disclosure that relates with the financial report, Disclosure is related with how a company is able to answer the following questions :

1. For who the information in revealed?

2. Why the disclosure has to be made?

3. How much information has to be revealed?

4. When does the information has to be revealed?

The above four questions have to be able to be answered by a company that will implement disclosure for knowing which parties will implement disclosure for knowing which parties will use the above information, the purpose or reason of the implementation of disclosure, the number of disclosure that is needed, and the right time for implementing disclosure (Raditya, 2012).

According to Islamic teachings Allah is The One Almighty God that has created nature and all of its contents, so from that absolute ownership belongs to Allah SWT (Permatasari, 2015:56). Humans in the face of the earth are only khalifa 
that have responsibilities for themselves, their actions and their doings to all other creations of Allah.

Humans have an obligation for following all orders of Allah and keep clear of all prohibitions of Allah. Humans have to apply the orders of Allah which are Islamic teachings in all aspects of life, because humans will be responsible for their actions in the Qiyamah later.

The application of these Islamic teachings also covers to the economical aspect. In the Islamic economy, accountability is needed for producing disclosure that is right, fair, and transparent. In the economic aspect one factor that needs to be paid attention is honesty that more specifically is accountability.

Haniffa (2002) declares that, "ISR is an extension of social reporting that not only covers the hope of the committee to the views of the people to the role of companies in economics but also the fulfillment of the spiritual perspective for report users that are muslim. The practice of Islamic social responsibility disclosure will be different with conventional social reporting because the basic principles are different although the basic concepts which are social responsibility and accountability are shown by both."

Disclosure of social responsibility according to the Islamic perspective is an effort for validating the stakeholders that are careful about the conformity and unconformity of syariah principles in a business activity for aiding them in making economic decisions and religious decisions for reaching falah (success in the life and afterlife).

Haniffa (2002) developed the ISR index based on six themes which are finance and investment, products, employees, borrowers, and environment. Othman and co. (2009) added one theme in the ISR disclosure index that they develop which is company governance. This research will use the ISR index that is designed by Othman and co. (2009). The following are the six disclosure themes of Islamic Social Reporting used in this research:

1. Finance and funding, this theme consists of 6 items which are riba funds/interest/non halal income, gharar (obscurity), zakat, policy of late payment of customer claims, Current value Balance Sheet and Value Added Statement.

2. Products and services, items consist of environmentally friendly products (Green Products), halal status of products, safety and quality of products and service of consumer complaints.

3. Employees, an item index that consists of work hours/days off/employee remuneration, employee training and education, employee gender equality, involvement of employees in management discussions, employee health and safety, environment, and others.

4. People, Items in this theme are factors such as sadaqah charity activities, wakaf, Qardhul Hasan, employee volunteer activities, education scholarships, and other social activities.

5. Living environment, that consists of information about living environment conservation, activities that do not produce pollution, education about the living environment, environmental audit, and environmental management system.

6. Company Governance, obedience to syariah, share ownership structure, profile of the directing committee, and anti-corruption policy. 
Not only just conventional banks that are known by the people, but syariah banks also appear that are now starting to be in great demand by the people. The meaning of syariah banks according to (Soemitra, 2010:61) is a financial institution that runs its business activities based on syariah principles and according to the types consists of Public Syariah Banks, Syariah Business Units, and Syariah Citizen Financing Banks. Syariah banks are banks that are known to forward the principle of profit and loss sharing.

So in syariah banks the presence of interest is not known, while conventional banks are known to always charge interest to their customers. According to Act no. 21 Year 2008 about syariah banking. The meaning of syariah banks are banks that run their business based on syariah principles and according to the types consists of Public Syariah Banks, Syariah Business Units, and Syariah Citizen Financing Banks.

Hypothesis

H1: There is a difference in the level of ISR disclosure between syariah banking in Indonesia and Malaysia.

Analysis Model

The analysis model from this research is begun with a checklist is financial reports of syariah banks in Indonesia and Malaysia, implementing scoring by granting a number 1 in every item that is disclosed, then comparing the scoring results between the two countries, after that it is continued with implementing an independent sample difference test t-test/Mann whitney for knowing hypothesis proof and knowing if there is an ISR difference in Public Syariah Banks in the two countries.

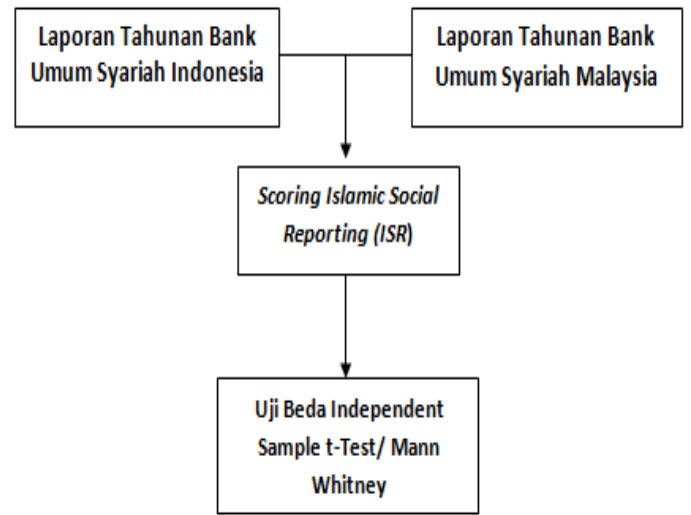

Figure 1 Analysis Model

\section{RESEARCH METHODOLOGY}

\section{Research Approach}

This research is implemented by using a qualitative approach method, which is research that focuses on the hypothesis test, measuring variables that are being researched and will produce summaries that are able to be generalized, and use statistical aid instruments

Variable Identification 
For answering the problem formulation and testing the hypothesis, the variable that is used in this research is the ISR total index that consists of six themes. Which are finance and funding, product and service, employees, people, living environment and company governance.

\section{Operatonal Variable Definition}

For providing a clear illustration about the variables that are used in this research, the variables are able to be defined as the following:

a. Islamic Social Reporting (ISR)

A variable that is used in this research is social responsibility of syariah banking that is seen through disclosure levels in Islamic Social Reporting based on the ISR index. The ISR index that will be used in this research uses an ISR index that is already designed by Othman and co (2009).

The value allocation in the content analysis that consists of 43 items of the ISR index is not measured for some times of a number of occurrences for each item in a one year period of disclosure, but as long as there is a minimal ISR disclosure of one time, the item is considered already present and given a value (score) of 1 . If the item is not found and declared in the company's report, the item will be given a value (score) of 0 . The Islamic Social Reporting disclosure level value is then counted with an equation (Ahzar and Trisnawati, 2013):

Disclosure level $=$ items fulfilled item maximum score

This score allocation does not rate the quality of companies through items in the ISR index, but only rates the level or the disclosure score in the ISR index. The rating of the disclosure index item will be identified and gathered from analysis or findings from company yearly reports.

\section{Types and Sources of Data}

Secondary data in this research are yearly reports of syariah banks that are in Indonesia and Malaysia. The yearly reports are obtained from websites of each bank or for yearly reports of syariah banking in Indonesia are able to be obtained from the website www.ojk.go.id, while the data for yearly banking report data in Malaysia is obtained from the official website of the Central Bank of Malaysia which is www.bnm.gov.my.

\section{Population and Sample}

The population in this research is the syariah banking that are present in Indonesia and Malaysia, that totals at 27 Syariah Public Banks, and consists of 12 Syariah Public Banks in Indonesia and 17 Syariah Public Banks in Malaysia.

The sample pickup technique that is used is purposive sampling. Samples are chosen by the researcher deliberately because there are some certain considerations with chosen criteria as the following:

1. Syariah banks in Indonesia and Malaysia that are stand-alone.

2. The syariah bank publishes yearly reports in a row in the years 2012-2014 in both countries.

3. The five largest syariah banks in Indonesia and Malaysia seen from their total assets.

\section{Analysis Technique}

In this research, the following steps are taken for implementing analysis in this research among others: 
1. Implementing a checklist which is with allocating a value of 1 if there is one item that is disclosed in the yearly report and a value of 0 if the item is not disclosed.

2. Implementing scoring which is by counting the Islamic Social Reporting disclosure value levels. The Islamic Social Reporting disclosure value levels are counted with the equation (Ahzar and Trisnawati, 2013):

Disclosure level $=$ items fulfilled item maximum score

3. Descriptive statistics test, descriptive statistics provide an illustration or description of a data that is seen from the average (mean) value, deviation standard, variant, maximum, and minimum.

4. Normality test, this test is implemented to know if data is distributed normally or not that is known by implementing the Normal Kolmogrov-smirnov test (Sujarweni, 2014:52). The pickup decisions from this test are

a. If sig $>0.05$ data is distributed normally

b. If sig $<0.05$ data is distributed abnormally

5. The hypothesis test is implemented with using an independent sample t-test. However if in the time of the normality test data is known to be distributed abnormally, the hypothesis test is implemented by using the mann-whitney test.

\section{Results and Discussion}

Based on the content analysis that is implemented, it is found that the average score of ISR disclosure levels of syariah banking in Indonesia during the years 2012-2014 is higher than the disclosure score levels of ISR syariah banking in Malaysia in the same period. The average implementation and disclosure of social responsibility that are implemented by syariah banks during the three years in Indonesia reaches $58.61 \%$ from a total of 43 disclosure items. While Malaysia obtained a score of $47.28 \%$ form 43 disclosure items and has a score difference of $10.86 \%$. This shows that the implementation of social responsibility and disclosure that is implemented by syariah banking in Indonesia is better than Malaysia. Which means that ISR index items that are disclosed by syariah banks in Indonesia is more descriptive than ISR index items that are disclosed by syariah banks in Malaysia.

\section{Descriptive Statistics Analysis}

Based on table 1, the average (mean) value amount of Syariah banking in Indonesia for the ISR score value is as large as 58.1393. The minimum value shows a number as large as 72.09. So it is able to be summarized that Syariah banking in Indonesia in disclosing ISR, disclose at an average of 25 items or if presented is as large as $58.14 \%$.

Table 1 Descriptive Statistics Analysis Result

\begin{tabular}{lccrcc}
\hline & N & Mean & $\begin{array}{c}\text { Std. } \\
\text { Deviation }\end{array}$ & Min & Max \\
\hline Indonesia & 5 & 58.1393 & 9.17659 & 41.86 & 72.09 \\
Malaysia & 15 & 47.2853 & 9.77583 & 34.88 & 62.79 \\
\hline Valid N (listwise) & 15 & & & \\
\hline \multicolumn{5}{c}{ Source: Processed Data }
\end{tabular}


While the smallest disclosure level which is as many as 18 disclosure items or $41.86 \%$ and the largest ISR disclosure score is as large as 31 disclosure items or as large A $72.09 \%$.

While the lowest disclosure level of syariah banking in Malaysia shows an average (mean) value of 47.2853 with a minimum value of 34.88 and a maximum of 62.79. This shows that the average disclosure of ISR that is implemented by Malaysian syariah banking based on the ISR index is as large as 20 items or as large as $47.28 \%$. The minimum value shows the lowest disclosure index that is implemented by syariah banking in Malaysia which is as large as 15 disclosure items or $34.88 \%$ and the largest disclosure level is 27 disclosure items or as large as $62.79 \%$.

\section{Normality Test}

Table 2 Kolmogorov-Smirnov Normality Test

\begin{tabular}{lcccc}
\hline Variable & Category & $\begin{array}{l}\text { Sig } \\
\text { Level }\end{array}$ & $\begin{array}{l}\text { Asymp.sig. } \\
\text { Value }\end{array}$ & Remarks \\
\hline ISR & Indonesia & 0.05 & 0.953 & Normal \\
& Malaysia & & 0.916 & Normal \\
& & & & \\
\hline
\end{tabular}

Source: Processed Data

Based on data from table 2 it is able to be known that Syariah banking data in Indonesia and Malaysia have a normal distribution. This shows a significance level of 0.953 of syariah banking in Indonesia, while the significance level is as large as 0.916. The two significance levels of Syariah banking in Indonesia and Malaysia show a larger significance levek than 0.05 so it is able to be declared normal, and fulfill the requirement for implementing the Independent Sample Ttest.

\section{Hypothesis Test}

Table 3 Levene's Table Test

\begin{tabular}{cccc}
\hline Variabel & \multicolumn{2}{c}{$\begin{array}{c}\text { Levene's test for } \\
\text { equality of variance }\end{array}$} & Remarks \\
\hline ISR & $\mathbf{F}$ & Sig & Homogenous \\
\cline { 2 - 3 } & 0.198 & 0.659 & \\
\hline \multicolumn{3}{c}{ Source: Processed Data }
\end{tabular}

In the Levene test column shows its significance level of 0.659. This shows that the significance level that is obtained is larger than $0.05(>0.05)$ so the significance level that is seen is the number in the t-test column.

Equal Variance Assumed

The Equal Variance Assumed t-test value shows a number of 0.004 (Table 4). This number shows that the significance value of ISR disclosure levels in Indonesia with syariah banking in Malaysia is smaller than 0.05 or $5 \%$, so the hypothesis in this research is accepted, and able to summarize that there is a significant difference between ISR disclosure levels of syariah banking in Indonesia and syariah banking in Malaysia 
Table 4 Independent Sample t-test

\begin{tabular}{llcc}
\hline \multicolumn{3}{c}{ Independent Sample t-test } \\
\hline & \multicolumn{1}{c}{$\begin{array}{c}\text { Sig. } \\
\text { (2tailed) }\end{array}$} & Remarks \\
\hline ISR & $\begin{array}{l}\text { Equal } \\
\text { variances }\end{array}$ & 0.004 & $\begin{array}{c}\text { H1 accepted } \\
\text { (there is a } \\
\text { significant } \\
\text { Assumed }\end{array}$ \\
$\begin{array}{l}\text { Equal } \\
\text { variances } \\
\text { not assumed }\end{array}$ & 0.004 & \\
\hline
\end{tabular}

\section{Discussion}

Based on content analysis results it is found that genrerally syariah banking in Indonesia has an ISR disclosure score that is higher than syariah banking in Malaysia in every year. This shows that syariah banking in Indonesia implements their social responsibility and disclose it better to the public and more open than syariah banking in Malaysia.

This content analysis result is different from results from the research of Sofyani (2012) that states that the performance level of syariah banking in Malaysia that is seen from the ISR disclosure level is better than the level of social performance of syariah banking in Indonesia. The difference occurs because the total syariah banking samples, period, and disclosure items that are used in this research are different, so the content analysis in this research is different and does not support the previous research results

The 3 themes that make ISR score values of Syariah banking in Malaysia lower than banking in Indonesia are:

1. Finance and Budgeting theme, Syariah banking in Indonesia has an ISR score that is higher than syariah banking in Malaysia in this theme, which is because in the policy item of delays in recievables, Malaysian syariah banking does not disclose about the policy at all.

2. People theme, in this theme the ISR score value between items are relatively different in every item neither in Syariah banking nor Malaysia every year. This is because the social programs that are implemented by Syariah banks in every year is different.

3. Living Environmnet Theme, in this theme the average item that is disclosed by Syariah banking in Indonesia and Malaysia is living environment conservation, an activity that does not make living evironment pollution (waste management, emission decomposition and others), and education. For the environmental management system theme, syariah banking only discloses $20 \%$. In this theme Syariah banks in Indonesia have a total score of 27 while Malaysia's score is 15.

The t-test Equal Variance not Assumed value shows a number of 0.003. This number shows that the ISR disclosure significance level of syariah banking in Indonesia than syariah banking in Malaysia is smaller than 0.05 or $5 \%$, so the hypothesis in this research is accepted ( $\mathrm{H} 1$ accepted), which is the presence of a significant difference in the Islamic Social Reporting disclosure index in syariah banking that is present in Indonesia and Malaysia.

The mentioned presence of an Islamic Social Reporting (ISR) value score in Syariah banks in Indonesia and Malaysia is caused by: 
1. There is not yet a rule that regulates about ISR index disclosure in yearly Syariah banking reports.

2. The meaning of ISR items need to be explicitized or written clearly, because items that the meanings are not written clearly will cause disclosure levels in each syariah bank in Indonesia and Malysia to be not yet implemented or found perfectly $(100 \%)$

3. Differences in disclosure levels that are implemented by Syariah banking in Indonesia and Malaysia are able to be caused by internal factors.

4. Large scale companies disclose more information because a large company size also means a large responsibility to the welfare of the stakeholders and environment and need a disclosure that is more complete and expansive. Other than that, larger companies have more financial resources, facilities, and human resources for more disclosure of Islamic Social Reporting, they will disclose more information, though without a standard or instruction that is able to be followed. This summary supports the previous research which is the research of Othman and co. (2009: 15) and Permatasari (2015:77)

\section{References}

AAOIFI. (2010). Accounting, Auditing \& Governance Standards for Islamic Financial Institutions. AAOIFI: Manama.

Ahzar, F.A., \& Trisnawati R. (2013). Pengungkapan Islamic Social Reporting pada Bank Syariah di Indonesia. Surakarta: Muammadiyah University Surakarta.

Bank Negara Malaysia. List of Licensed Banking Institutions in Malaysia. (Online).(www.bnm.gov.my/index.php?ch=li\&cat=iib\&type $=$ IIB \&fund $=0$ $\& \mathrm{cu}=0$, accessed on 12 Januari 2016).

Evans, T. G. (2003). Accounting Theory: Contemporary Accounting Issues. United States of America: Thomson

Global Islamic Financial Reporting. Islamic Finance Country Index 2014. (Online). (http://www.gifr.net/gifr_2014.htm, accessed on 25 Februari 2016)

Global Reporting Intiative. (2013). Pedoman Pelaporan Keberlanjutan. Amsterdam: Global Reporting Initiative.

Haniffa, R. (2002). Social Reporting Disclosure-An Islam Prespektif. Indonesian Management \& Accounting Research, 1(2), 128-146.

Hasan., \& Harahap. (2010). Exploring Corporate Social Responsibility Disclosure: The Case of Islamic Banks. International Journal of Islamic and Middle Eastern Finance and Management, 3(3), 203-227.

Othman., \& Thani. (2010). Islamic Social Reporting of Listed Companies in Malaysia. The International Business and Economics Research Journal, 9(4), 135.

Othman dkk. (2009). Determinant of Islamic Social Reporting Amoung Top Shariah-Approved Companies in Bursa Malaysia. Journal of International Studies, 12.

Permatasari, V.S. (2015). Pengaruh Ukuran Perusahaan, Profitabilitas, dan Ukuran Dewan Direksi Terhadap Indeks Islamic Social Reporting Pada Perusahaan yang Terdaftar dalam Jakarta Islamic Index Tahun 2011-2013 
. Thesis not Published. Surabaya Faculty of Economics and Business Airlangga University.

Raditya, AN. (2012). Analisis Faktor-Faktor yang Mempengaruhi Tingkat Pengungkapan Islamic Social Reporting (ISR) pada Perusahaan yang Masuk Datar Efek Syariah (DES). [Thesis]. Depok: Faculty of Economics Indonesia Uniersity.

Soemitra, A. (2010). Bank dan Lembaga Keuangan Syariah. Jakarta: Publisher Kencana Prenada Media Group.

Sofyani, Ulum, Syam, and Wahjuni. (2012). Islamic Social Reporting Index Sebagai Model Pengukuran Kinerja Sosial Perbankan Syariah (Studi Komparasi Indonesia dan Malaysia). Malang: Muhammadiyah University Malang.

Sudarmadji, A.M., \& Sularto, L. (2007). Pengaruh Ukuran Perusahaan, Profitabilitas, Leverage, dan Tipe Kepemilikan Perusahaan terhadap Luas Voluntary Disclosure Laporan Keuangan Tahunan. Proceeding PESAT (Psikologi, Ekonomi, Sastra, Arsitek, \& Sipil). Depok.

Sugiyono. (2012). Metode Penelitian Kuantitatif, Kualitatif, dan R\&D. $17^{\text {th }}$ print. Bandung: CV Alfabeta.

Sujarweni, V Wiratna. (2014). SPSS Untuk Penelitian. Yogyakarta: Publisher: Pustaka baru press.

www.bi.go.id, accessed on 12 Januari 2016.

www.ojk.go.id, accessed on 16 Januari 2016. 